University of Louisville

ThinkIR: The University of Louisville's Institutional Repository

\title{
The Chinese civil service examination's impact on Confucian gender roles.
}

Albert Oliver Bragg

University of Louisville

Follow this and additional works at: https://ir.library.louisville.edu/honors

Part of the Asian History Commons, and the History of Gender Commons

\section{Recommended Citation}

Bragg, Albert Oliver, "The Chinese civil service examination's impact on Confucian gender roles." (2015). College of Arts \& Sciences Senior Honors Theses. Paper 71.

http://doi.org/10.18297/honors/71

This Senior Honors Thesis is brought to you for free and open access by the College of Arts \& Sciences at ThinkIR: The University of Louisville's Institutional Repository. It has been accepted for inclusion in College of Arts \& Sciences Senior Honors Theses by an authorized administrator of ThinkIR: The University of Louisville's Institutional Repository. This title appears here courtesy of the author, who has retained all other copyrights. For more information, please contact thinkir@louisville.edu. 


\title{
The Chinese Civil Service Examination's Impact on Confucian Gender Roles
}

\author{
By \\ Albert Oliver Bragg \\ Submitted in partial fulfilment of the requirements for \\ Graduation summa cum laude \\ University of Louisville
}

May 2015 


\section{Introduction}

The Chinese Civil Service Examination was an institution that lasted virtually uninterrupted for roughly thirteen-hundred years, beginning during the late Sui Dynasty in 587 C.E. and ending in 1904 shortly before the collapse of the Qing Dynasty ${ }^{1}$. While the structure and number of examinations varied widely from dynasty to dynasty, the fundamental content of the examinations was to test one's knowledge of the Confucian classics: The Analects, The Book of Mencius, The Book of Changes, The Book of Documents, The Book of Poetry, The Book of Rites, and the Tso Chuan. The broad purpose of the civil service examinations was to select a pool of viable candidates who were all trained in the same Confucian classics to be appointed as imperial officials at various locations and positions. For Chinese families, producing degreeholding sons was considered the greatest socio-political achievement, therefore a son's education for the examination would begin as early as possible and continue until their success, only being interrupted by marriage and fatherhood.

Since the examinations covered the same Confucian literary canon, the examination existed as a way to propagate the Confucian worldview, ethics, and values among civil officials. Confucianism emphasizes that the foundation of an ideal government begins with good family relationships. These family relationships are hierarchical based on generation (father-son), gender (husband-wife) and age (siblings). If a ruler or official applies the principles governing family relationships to harmonize human relationships outside the family then he will have the potential to be a good ruler by relating to his subjects in a way a family head does to his family

\footnotetext{
${ }^{1}$ Miyazaki, Ichisada. China's Examination Hell (New Haven: Yale University Press) 136-7.
} 
members. In other words, the political ruler-subject relationship should mimic the familial fatherson relationship.

Early English language scholarship on the Civil Service Examination focused on its competitive nature, regarding it as a high risk but high reward path for social mobility. Ping-ti Ho's The Ladder of Success in Imperial China (1962) established the paradigm that contemporary scholars use in their interpretations of the Civil Service Exam. He situated the examination system within the broader study of social mobility in imperial China, analyzing the structure of social mobility and highlighting the importance of success in the examination in materializing one’s upward mobility.

Ichisada Miyazaki’s China's Examination Hell (1970) examined every aspect of the Civil Service Examinations in the order that a candidate would follow to achieve an official position. This process starts from rituals of luck that begin even before birth, the grueling childhood preparations, and then completes with taking the examination at local, regional, metropolitan, and palace levels. He paid special attention to the draconian rules of order that examination candidates must abide by while they are taking their exams, and compared the rough conditions of the Civil Service Exams to the contemporary Japanese College Entrance Examinations in the 1970s—both of which qualify as an 'Examination Hell.' While he did not explore how the Civil Service examination worked outside China (in Vietnam or Korea), Miyazaki provided an excellent general knowledge base of the structure of the examinations and the intricate process of attaining a degree and holding a government position. 
John Chaffee’s The Thorny Gates of Learning in Sung China (1985) studied the changing examination system, the brief prohibition of merchants, artisans, and monks from taking the exam, the skewed distribution of successful and unsuccessful candidates, examination riots, and the broader examination culture of the Song Dynasty. The examination culture that he investigated includes rituals, stories, and the expectations placed on young men who attempt to succeed.

Contemporary scholars approached the Civil Service Exam from a broader scope of studying Chinese History, and their interpretations shed light on the complex relations between the long term trend of commercialization and the changing Confucian culture, class relations, and gender norms. Some scholars paid special attention to the female gentry and their relationships with their men who took the exams, obtained degrees, and held offices away from home. Dorothy Ko and Susan Mann’s works did not explicitly focus on the Civil Service Examination, but their study of women's history and their gender analyses were in line with my argument that the Civil Service Examination had a significant impact on gender relationships.

\section{Dorothy Ko's Teachers of the Inner Chambers: Women and Culture in Seventeenth} Century China (1994) examined the gender relationships of gentry households in the Lower Yangtze area in the seventeenth century, seeking to rectify misconceptions developed since the May Fourth Movement that saw Chinese women as victims who were "whipped into submission to their fathers, husbands, and sons"2 She argued for women's informal power in the domestic realm and their vested interests within the Confucian framework. She analyzed how women

\footnotetext{
${ }^{2}$ Ko, Dorothy. Teachers of the Inner Chambers. (Stanford: Stanford University Press): 7
} 
redefined the boundaries between the 'inner' and 'outer' worlds, the ideal of proper womanhood, and the ideal of "talent, virtue, and beauty" through their writings and practices.

Susan Mann’s Precious Records: Women in China’s Long Eighteenth Century (1997) argued for the central role of women's writings in reinforcing the state-promoted discourse of “moral wives” as the social moral fiber of the High Qing society. By studying gentry women’s writings and biographies of gentry women written by Confucian gentry men, Mann sought to construct the historical agency of writing women in creating the High Qing culture.

Cultural historian Timothy Brook’s The Confusions of Pleasure: Commerce and Culture in Ming China (1999) placed the Civil Service Examination within the context of the rapid commercialization and rise of the merchant class during the Ming. His book provides information on the socioeconomic transformation of Ming China as well as how commerce and commercial values redefined Confucian values, the examination culture, the social structure, and gender norms in late Ming society. Most importantly, his discussion of commercial printing illustrated the demand and supply of women's poetry, painting, and other artifacts, a point that will be elaborated upon in my own study. Also in 1999, Kang-i Sun Chang and Haun Saussey published the impressive Women Writers of Traditional China: An Anthology of Poetry and Criticism, which translated many Chinese women's poems into in English. The anthology provides the bulk of my primary sources of Chinese women's writings to analyze gentry women's connections with the Civil Service Examination.

Susan Mann's The Talented Women of the Zhang Family (2007) documented the lives of the female literati within a gentry family in the Lower Yangtze region—-the Zhangs, during the late nineteenth century. The biographical account of three generations of talented literary women 
suggests that in the absence of male heads of household, gentry women became the moral center as well as economic backbone for the survival of the gentry household. More recently, Benjamin Elman’s Civil Service Examinations and Meritocracy in Late Imperial China (2013) follows the suit of Ping-ti Ho on studying the Civil Service Examination and social mobility. However, Elman differs by focusing explicitly on the role of the Exam in determining social mobility, whereas Ho focused primarily on social mobility in general with the Exam as a part of that mobility.

This paper approaches the Civil Service Exam through the writings of women during the Ming and Qing, centering on a less studied aspect—-the impact of the examination on gender relationships among the gentry class. The central argument is that since the examination candidates and degree-holding officials lived itinerant lives away from home, the human relationships within the family became increasingly strained as shown in many women's writings. Because of this, the Civil Service Examination that assesses one's knowledge of Confucianism placed an ironic burden on the familial relationships that serve as the cornerstone of the Confucian moral order. This argument is comprised of three sections.

The first section examines the common theme of separation and alienation in women's writings. Women of literati families were often separated from their fathers, husbands, brothers, and sons who studied away from home, traveled from examination hall to examination hall, and served offices far away. Some women's writings on this theme simply expressed their longing for their missing family members, while others contain a bitter tone or even sharp criticism towards the examination system as an institution that separates families. Some women writers lamented over the human sacrifice the examinations demanded when their husbands or sons died during their travels or committed suicide after failing the examination multiple times. This point 
especially exemplifies how the Civil Service Examination resulted in the dissolution of the traditional Confucian family structure and ideal gender norms, as women who were left alone had to tend to the emotional, economic, ritual, and social needs of the family estate while the men traveled to take the examinations and served the imperial state.

The second section explores women's diverse roles in the inner chamber as their men's confidants, moral supporters, children's instructors, and as wives and mothers. By fulfilling those expected gender roles, those women became involved not only in their men's private lives but also in their public ones, and therefore were not completely separated from the examination system which excluded female participation. Gentry women held great informal power in domestic matters, and they exercised this power to the benefit of the family and the advance of their interests without challenging the Confucian gender norms. Most women nurtured a good environment for their children to learn, and for the most part conformed to the Confucian models of virtuous women. A noticeable change over time was that many gentry women gained the power to influence their husbands’ decision-making.

The third section explores the "double burden" gentry women shouldered due to the examination system. Besides being the home-makers as wives and mothers, they often had to be economic contributors out of necessity. Since gentry men were supposed to study diligently for the exams, they often did not make significant economic contributions to the household. Gentry women made important economic contributions to the family by being household managers, selling their artistic works such as calligraphy, painting, and embroidery, as well as publishing their poetry and writings through commercial venue. Sometimes those women functioned as the redeemers of the declining gentry households through their economic activities. Although their economic explorations gave them a presence outside the inner chamber, they justified their 
activities by emphasizing their roles as the helpers to their men and redrawing the boundaries between inner and the outer spheres.

Together, these three sections jointly argue that the Civil Service Examination affected the basic human relationships upheld by Confucianism. The prolonged separation of gentry men and women due to men's travels to examination halls and offices both caused distress in those women's emotional worlds, but it also enabled gentry women to exercise greater informal power in the households, to extend their lives into the public realm, and to influence the decisionmaking of their men. In other words, women influenced the world around them indirectly through influencing their men. 


\section{Section One: Alienation}

The Civil Service Examination required years of study and as such, boys typically began their education as early as possible. Many boys in gentry households were given pre-school education using primers, typically began their formal education around the age of eight and were expected to complete their classical education at fifteen ${ }^{3}$. In preparing for the examination, candidates constantly traveled away from home. By examining gentry women's writings, we can get a closer look at their perspectives on the Civil Service Examinations. The most prominent theme of their writing was the overwhelming sense of alienation. Susan Mann noted that married women of elite families often wrote "of sexual privation, of loneliness, of boredom, of resentment, and of physical abuse."4 These feelings of alienation stem from absence of fathers, husbands, brothers, and sons who were typically away either taking the examinations or preparing for them. For elite women, the examination was a system that demanded significant human sacrifice both in terms of the separation of family members as well as the eternal loss of their loved ones due to unexpected death.

Many poems contained in the collection Women Writers of Traditional China: An Anthology of Poetry and Criticism express gentry women's longing for their fathers, husbands, brothers, and sons who were away taking the Civil Service Examinations. Zhang Hongqiao (fl.

\footnotetext{
${ }^{3}$ Miyazaki, Ichisada. 1976. China's Examination Hell (New Haven: Yale University Press) 16

${ }^{4}$ Mann, Susan. Precious Records. (Stanford: Stanford University Press) 55
} 
ca. 1400) frequently used the imagery of migratory geese to symbolize the itinerant lifestyle of her husband who was an examination candidate:

Day and night, I look for a wild goose flying back from the north. ${ }^{5}$

We see each other thousands of times, but only in dreams;

During the long day I envy the pair of wild geese glimpsed from my terrace ${ }^{6}$

Similarly Shen Qionliang (1488-1505), a female scribe and later chancellor at the imperial court, wrote on separation from the perspective of a sister who wanted her brother to pass the Civil Service Exam so that they could serve the emperor together:

No matter how many candles are burnt, my dreams are of no avail, Many a jade hairpin broken, I have yet to return home. Year after year I expect your name to appear on the golden list, Together we can mend the robe of the mountain dragon. ${ }^{7}$

The poet Shen Yixiu (1590-1635) also expressed lament over the absence of her husband Ye Shaoyuan who traveled to the capital:

On an Autumn Day, I wait for Zhongshao's [Ye Shaoyuan's] Letter from the Capital, Which Never Arrives

The chill of the west wind sets in, dyeing my fragrant skirt green, Your white-haired mother waits for your return every evening at the door.

Isn't there a single goose left in the capital?

Must you deprive the paired carp of their silken voice?

Wang Can climbs the tower, pondering-

When will Qin Jia at the frontier write to his wife?

All the white duckweed is swept away, and the waves turn green, Pine trees swish in the wind, dew congeals on the paulownia, yet

\footnotetext{
5 "Farewell to Lin Hong" from Chang, Kang-i Sun and Haun Saussey. Women Writers of Traditional China (Stanford: Stanford University Press) 151

${ }^{6}$ Ibid 152

7 "To My Younger Brother Pu on His Spring Examination" from Chang, Kang-i Sun and Haun Saussey. Women Writers of Traditional China (Stanford: Stanford University Press) 166
} 
behind the evening curtains: emptiness. ${ }^{8}$

These poems from wives, sisters, and mothers all show a similar sense of loneliness in the absence of their male family members who were away because of the examinations. Wild geese according to Chinese legend were messengers bringing letters to people living far away. The frequent usage of this imagery expressed women's strong desire to communicate with their men who were far away and absent from their lives.

Unfortunately, the dangers of traveling (accidents, disease, and bandits) as well as the unbearable frustration of spending one's life preparing for the examination only to fail again and again claimed the lives of some gentry men - they were unable to ever return home to their wives, mothers, and children who were waiting for them. Bo Shaojun (d. 1625) wrote a chilling series of quatrains in response to her husband's suicide after his seventh failure at the Civil Service Examination. A year later, still overcome with grief, Bo also took her own life in order to follow her husband. ${ }^{9}$

Quatrains from "Mourning for the Dead"

27

Through seven battles in Jinling, your morale never flagged-

Alas! This brave hero gave his life at the scholar's cold window.

Glory at the civil service exams lured you to this end;

I want to kick over the Gold Mountain, let the Great River flow dry!

31

The yellow crane has gone afar, never to return-

Our son wailed, our daughter cried out, pressing around you.

You turned your head away, uncaring! Abandoning them!

\footnotetext{
8 “On an Autumn Day, I wait for Zhongshao's [Ye Shaoyuan's] Letter from the Capital, Which Never Arrives" from Chang, Kang-i Sun and Haun Saussey. Women Writers of Traditional China (Stanford: Stanford University Press) 270-271

${ }^{9}$ Chang, Kang-i Sun and Haun Saussey. Women Writers of Traditional China (Stanford: Stanford University Press) 218
} 
You let go and fell down the Ten Thousand Foot Cliff. ${ }^{10}$

Women who lost their husbands to suicide or accident expressed resentment and frustration at the Civil Service Examination as an institution requiring significant human sacrifice, both in time and energy spent away from the family as seen in the poems of Zhong Hongqiao and Shen Yixiu, as well as more literally in the poems of Bo Shaojun where she blamed the examination system for the death of her husband. Other poets frequently described their loved ones as withered or thinned after returning from the exams.

These writings that express feelings of loneliness or lamenting the loss of their loved ones illustrate the negative effect of the civil service examination system on family relationships defined by Confucius. It was difficult for a young man to perform the Confucian obligation of filial piety to his parents if he had to focus on the examination. Likewise it was difficult for women to practice the Thrice Following (faithfulness to their fathers, husbands, and sons) if those men are absent due to study or travel. As a result, the absence of male family members for prolonged periods of time naturally led to the gradual change of women's gender roles, a point I will explore in depth in my discussion of women's economic roles. Since women of high social standing were more likely to follow the Confucian guidelines of inner and outer circles, if the husband was away taking the examination, the wife had to take responsibility of managing the household in addition to conforming to the expectation that she be the moral center of the household.

If we compare the gendered life paths of male and female gentry, it is not hard to see that although gentry women felt alienated from their exam-taking and office-holding men, gentry

\footnotetext{
10 "Quatrains from "Mourning for the Dead"” from Chang, Kang-i Sun and Haun Saussey. Women Writers of Traditional China (Stanford: Stanford University Press) 219
} 
men away from home could have developed broader social networks and meaningful relationships from their school classmates, examination year peers, and mentors or patrons ${ }^{11}$. The center of a man's life shifted from their families to their public lives, while women's lives were almost always family centered. Dorothy Ko provided the story of the gentry-offical Ye Shaoyuan and his wife Shen Yixiu. At an early age, Ye was given up for short-term adoption by the Yuans as part of the long standing marriage and adoption alliance between the five most powerful families in the Jiangnan region. ${ }^{12}$ Later, Ye and the poet Shen Yixiu were arranged to be married. However, for five years the couple hardly ever spent any time together. Instead, Shen was to stay at her mother-in-law's house while Ye stayed in his father's house to study diligently for the examination. Ko noted that:

“Ye Shaoyuan’s year-by-year journal shows that for twenty years between his marriage and his attainment of the metropolitan degree, he sojourned in the residences of senior scholars five time ... and he traveled to Kushan, Jiangyan, and Nanjing to take the examinations twelve times, each trip lasting from two weeks to three months. For the trip to the capital for the metropolitan examination, he was away from home for seven months." 13

In addition to the prolonged absences of Ye from the household due to the examination, he was entwined in the same politics of elite family alliances that resulted in his adopting out and arranged marriage. From the male communal perspective, these family alliances treat the intermarriage of elite families as serving the interest of the family purely as a corporate unit $^{14}$. Such practices distanced the male head of the household from the individual interests of his family members, exemplified by the misfortune that befell their daughter Ye Wanwan who died

\footnotetext{
${ }^{11}$ Mann, Susan. Precious Records. (Stanford: Stanford University Press) 51

${ }^{12} \mathrm{Ko}$, Dorothy. Teachers of the Inner Chambers. (Stanford: Stanford University Press 186

${ }^{13}$ Ibid 190

${ }^{14}$ Ko, Dorothy. Teachers of the Inner Chambers. (Stanford: Stanford University Press) 195
} 
at the age of 22 after seven years of being neglected by her husband whom had been arranged for her at the age of one because he was the son of Ye's friend. ${ }^{15}$

\section{Section Two: Women as the Moral Center of the Family}

The separation of elite men from their women due to the exam culture created a situation where elite women were frequently left to themselves in the household. Over time, the gender roles those Confucian women were expected to play gradually shifted. Traditional Confucian women were supposed to practice the Thrice Following, and their identities and loyalties were determined by their riles as dutiful daughters to their fathers, faithful wives to their husbands, and widowed mothers who followed their sons. Yet the absence of men from home left plenty of room for women to carve out new roles for themselves in fulfilling their Confucian duties to their families. This section will explore the domestic roles women were expected to fulfil, as well as those shifted roles they had to fill in as a result of the examination system. Women were the moral center of their families, and their traveling men relied on the moral order those women maintained for emotional support and stability. The increasing importance of women at home enabled them to exert influence over household affairs in the absence of male family members.

\footnotetext{
${ }^{15}$ Ibid 195
} 
According to Susan Mann, the separation of inner and outer spheres placed women in a role of moral authority within the household:

"In High Qing discourse the principle of bie — separate spheres—is invoked to stress that wives and mothers inside the home embody the moral autonomy and authority on which husbands and sons must rely on to succeed outside. All are part of a family system that constitutes a seamless, unitary social order centered on the home and bounded by the outer reaches of the imperium." 16

This expectation that women be the moral center of the household can be accomplished in a few ways. One of these ways is through fulfilling the expected roles of virtuous women. Mencius's mother served as a moral exemplar for women to follow-women were supposed to be moral exemplars for their sons who strove for achievement in the exams:

"Mencius's mother, a widow, sold her weaving to support her son's studies. Distraught over his conduct (the young Mencius fell in with a bad crowd and neglected his schooling), one day she dramatically slashed the cloth on which she was working and declared to her shocked son that his neglect of his studies was just as destructive: "if you do not study now, you will surely end up as a menial servant and never be free from troubles. The same thing would happen to a woman who supports herself by weaving if she were to give it up."”17

This story of Mencius's mother provides one of many moral exemplars women were to follow in Liu Xiang's (c. 18 B.C.E) Biographies of Exemplary Women, a book that was used in instructions for young women in early childhood education.

Many gentry women played active roles in their sons’ education. Guo Ruopu (1592- ca.

1681) wrote on her experience in refurbishing a found boat for her son to use as a study.

Refurbishing a Boat for my Son, Can, to Use as a Study

I was always conscience-stricken

Before the zeal of those ancient mothers

Until I found it, at a scenic spot

Beside a bridge where in other days

It used to skirt the trees,

Following the chaste moon (not like

\footnotetext{
${ }^{16}$ Mann, Susan. Precious Records. (Stanford: Stanford University Press) 15

${ }^{17}$ Mann, Susan. Precious Records. (Stanford: Stanford University Press) 145-6
} 
Those craft that cruise the mist In search of frivolous ladies).

You have long hoped to study

In Yang Zhu's school, but now

Passers-by will see the scholar Mi Fu's barge.

Don't mistake it for a pleasure boat;

I've fixd it up with old coverlets

Woven of blue silk. ${ }^{18}$

Although Guo Ruopu modestly said that she could not compare herself with the ancient mothers mentioned in the Biographies of Exemplary Women, she was willing to work hard to provide her son a study so that he can have adequate transportation to his schooling for the examination as well as a mobile floating workstation.

Zou Saizhen (fl. 1496) wrote encouraging poems to her son, advising him to focus on his study, be proud of the learning legacy of his family, and not to take up drinking and to focus on his studies:

Encouraging my Son Shao to Study and Abstain from Wine

"Your benevolent forbears passed on purity and honor

To you, my son, who are now no longer a child.

Heed your father's teachings and strive to emulate him;

Trace things to their roots and know the value of study.

Do not set out on the easy path of drinking wine, Instead punt your boat upstream.

And though your wife may have no goods to pass on, The Classics and Histories will be your family’s legacy.”19

By consciously emulating the moral exemplar of the mother of Mencius and providing moral instruction to their sons, those gentry women exerted their motherly influence on their sons' education.

\footnotetext{
18 "Refurbishing a Boat for My Son, Can, to Use as a Study" from Chang, Kang-i Sun and Haun Saussey. Women Writers of Traditional China (Stanford: Stanford University Press) 304

19 "Encouraging my Son Shao to Study and Abstain from Wine" from Chang, Kang-i Sun and Haun Saussey. Women Writers of Traditional China (Stanford: Stanford University Press) 169
} 
Some gentry women were at the center of their families' moral redemption when disasters and misfortunes dishonored the family. In Sarah Schneewind's A Tale of Two Melons, the Zhang family women displayed this heroism. Around the year 1390, a man by the name of Zhang Qian was falsely arrested for a crime committed by a man of the same name and both he and his brother who submitted a petition were executed ${ }^{20}$. Qian's brother Guan was regarded as an exemplar of the perfect relationship between brothers for his willingness to die helping his brother. When the emperor exiled the sons of Zhang Guan, Zhang Da and Zhang Yi, the wives and daughters of the Zhang family gained regard for being the center of their family's redemption. The daughters and wives of the Zhangs kept the family together, even in exile, handled the household economy, and cultivated their sons' education. Eventually a grandson of the Zhang family Zhang Jian earned a jinshi (the highest ranked) degree in the Civil Service Examination $^{21}$, ensuring that the Zhangs could return to their native Jurong county from their exile on the frontier. Such an account of the Zhang family showed the tenacity and the resolve of the Zhang women in holding the family together in extremely hard circumstances.

Besides fulfilling their Confucian gender roles and being the moral center for their family, gentry women in the inner chamber were also the emotional support for their family members. Because of the itinerant lives of their men during the Ming and the Qing, gentry women nurtured a good environment for their children's education, and tended to their emotional needs. Chai Jingyi (mid-1 $17^{\text {th }}$ Century) wrote a poem consoling her son who failed to acquire a degree in the examination after his third attempt:

Sustaining my Son, Yongji

\footnotetext{
${ }^{20}$ Schneewind, Sarah. A Tale of Two Melons (Indianapolis: Hackett Publishing Company Inc.) 38-57

${ }^{21}$ Schneewind, Sarah. A Tale of Two Melons (Indianapolis: Hackett Publishing Company Inc.) 49
} 
Have you not seen-

Night after night in ducal halls, sumptuous banquets are laid,

But before half-emptied goblets and cold meat dishes, who cares about

Talent?

After three trips to Chang'an, you have not attained your goal, Wild-haired, grimy-cheeked, you have come back home.

Alas! This world's humors change a thousand times a day, To ride in a carriage and dine on meat does man covet and strive.

So, read your books, play your lute, and therein find your pleasure,

Since times of old, thinkers wise endured in poverty. ${ }^{22}$

This poem reveals the supportive role a mother played in her son's life. Despite his failue, the mother pointed him toward the joy and pleasure of a poor scholar's life-with books and music as his companions. Here, women were expected to be a safe emotional harbor for their men who failed in their pursuit in the competitive world outside.

In the absence of their husbands, gentry women were able to nurture their sons’ passion for learning and provide them moral instruction to sustain them. In times of family crises, gentry women were able to endure hardships to maintain family unity and stability. They provided their traveling men the emotional support thet needed, as Susan Mann astutely stated that women of the inner chambers formed the emotional and moral support that their men rely on in order to succeed in the outer sphere.

\footnotetext{
22 "Sustaining My Son, Yongji" from Chang, Kang-i Sun and Haun Saussey. Women Writers of Traditional China (Stanford: Stanford University Press) 389
} 


\section{Section Three: Women's Economic Support for Husbands and Sons taking the Examinations}

Wives of elite families were expected to be the managers of the household and everyone within. Susan Mann succinctly defines this role as "managing everything"23, by which she means that women were expected to be in charge of all homemaking tasks, such as the cleaning, cooking, training maids, and early childhood education for both male and female offspring. However, due to necessity, women also had to contribute to the financial wellbeing of the household. This income could come from a myriad of different sources. Susan Mann’s account of a different Zhang family than the one discussed in the second chapter acquired their income from selling their calligraphy and embroidery. Dorothy Ko writes about the occupation of itinerant teaching as a transient community between the inner and outer worlds. Commercial

\footnotetext{
${ }^{23}$ Mann, Susan. Precious Records. (Stanford: Stanford University Press) 36
} 
publishing also flourished during the Ming dynasty and published collections of women's poetry were especially popular.

Susan Mann's account of the Zhang family (a different Zhang family than the one discussed in Sarah Schneewind's work) follows the history of a literati family who were acclaimed calligraphers and embroiderers. The family was well known for their calligraphy made in the stele style, inspired by rubbings taken from stone engravings and well accepted for its angular style and sense of strength. ${ }^{24}$ This style would be passed on to the daughters of the family who would then sell their calligraphy in order to support the family while the heads of the household were away. The Zhang family also supported themselves by selling their embroidery in the absence of the male head of the household. Additionally, this passage shows that women also had a role in early education of scholars:

“In her husband's absence, Qieying's mother took over Yuesun’s training as a scholar. A tutor was too expensive. She also began teaching all four of the girls how to do needlework. Qieying and Guanying, who had done simple stitchery for some years, were soon producing fine embroidery. As months and then years passed without word or money from Qieyang's father, her mother began relying on Qieyang and her sister to help support the family."25

The historical account of the Zhang family shows that the talented women of the family were able to provide economic support for the family in the absence or death of the male heads through their calligraphy and embroidery, emphasizing the dual burden of having to both contribute to the family's economic wellbeing as well as fulfilling the Confucian norms of thrice following and being the moral center of the household. Additionally, the talented women of the Zhang family demonstrate the applied professionalization of women’s learning.

\footnotetext{
${ }^{24}$ Mann, Susan. The Talanted Women of the Zhang Family. (Berkeley: University of California Press) 51

${ }^{25}$ Ibid 67
} 
Dorothy Ko writes about a group of women called the teachers of the inner chambers. The teachers of the inner chambers were daughters of literati families who served as paid tutors and were seen as a professionalization of women's learning as an economic resource ${ }^{26}$. The teachers of the inner chambers were hired by high officials for the purpose of teaching poetry and literacy to their daughters in order to make them more attractive for marriage into other high ranking families. While this seemed contrarian to the Confucian ideals of inner and outer spheres, these tutors were still following Confucian norms since male tutors teaching girls was seen as an egregious breach of gender segregation. As such, these women lived itinerant lives as professional tutors, deviating significantly from the gender norms of inner and outer sphere but still considered respectable by the literati that hired them. ${ }^{27}$

The Ming dynasty saw a dramatic increase in the presence and power of the merchant class. With this, commercial publishing also saw a significant boom, initially selling volumes of examination materials and model essays but quickly expanded to the markets of books to be read for leisure. ${ }^{28}$ Eventually, collections of women's poetry would be sold in the commercial printing market. There was certainly a market for women's poems: Dorothy Ko notes the view of women as “naturally fit” for poetry and their poetry was seen as better then men’s because it was not corrupted by the examination:

"Not expected to conform to conventions and spared from the rote memorization of the Classics, a woman was free to create literature purely as an expression of her true self. Hence women's writing was a corrective for the stylized and formulaic prose and verse purveyed by male scholars. . . Not only was a female writer different from a male, she was better."29

\footnotetext{
${ }^{26}$ Ko, Dorothy. Teachers of the Inner Chambers. (Stanford: Stanford University Press) 126

${ }^{27}$ Ko, Dorothy. Teachers of the Inner Chambers. (Stanford: Stanford University Press) 128

${ }^{28}$ Brook, Timothy. The Confusions of Pleasure (Berkeley: University of California Press) 129

${ }^{29} \mathrm{Ko}$, Dorothy. Teachers of the Inner Chambers. (Stanford: Stanford University Press) 52
} 
Wu Guofu, a male commentator in the preface of a poetry collection of Wang Duanshu echoes this sentiment: "Talented ladies from the inner quarters have nothing to do with the civil service examination. Since they do not aspire to fame, their words are true. Nor are they distressed by the rise and fall of empires. Since national affairs are not where their minds focus, their words are detached.” ${ }^{30}$ This sentiment that women were more impartial and honest for not being a part of the examination system fueled the demand for poems written by women as a fresh perspective on the world. While women were not selling their collections of poems out in the marketplace, men would often gather their poems to sell in these collections. Therefore I consider this to be an indirect act of women providing economic support for their families. This indirectness is illustrated by the Three Wives Commentary of the Peony Pavilion. The Three Wives Commentary of the Peony Pavilion is a collection of writings and poems written by the three wives of Wu Ren (each having died with the next continuing the project with Wu Ren being the final compiler) in the margins of the play The Peony Pavilion ${ }^{31}$. The Peony Pavilion itself is the story of love that crosses the boundaries of death, making the Three Wives Commentary that much more heartbreaking to read.

Another way women contributed to the economic wellbeing of the household was through the arranged marriages of the children of the household. Typically, as shown in chapter one, men are supposed to be in charge of the arranging of marriages in order to secure the family's best interests for the future. ${ }^{32}$ However, as women began taking up the task of providing

\footnotetext{
${ }^{30} \mathrm{Ibid} 52$

${ }^{31}$ Ko, Dorothy. Teachers of the Inner Chambers. (Stanford: Stanford University Press )73

${ }^{32}$ Ibid 195
} 
for the household, they also became more involved in the marriage arrangement process, especially as companionate marriages became more and more acceptable.

Women of elite families were expected to manage both the household as well as provide economic support for the family. Women contributed to the income of a household through the selling of calligraphy and embroidery, as seen in the example of the Zhang family, in order to afford to maintain their lifestyle and to prepare the young son for the examinations. Talented women of literati families could take up the professional role of a teacher of the inner chamber and educate young women of other literati families in order to make them more desirable in the marriage market. As a result of the booming commercial printing culture during the Ming dynasty, women's writings and poetry were successfully sold and well liked as shown in the popular sentiments that women were not corrupted by the examination system and their writings were more honest. Finally, women were able to have an increased role in determining the arranged marriages of their children, thereby having a direct role in continuing a family's success. 


\section{Conclusion: The Impact of the Examinations on Confucian Gender Roles}

From the previous sections of women's alienation, women’s moral obligations, and women’s economic contributions, we can develop conclusions about the examination system's impact on Confucian gender roles. First, the examination system had profound negative effects on the wellbeing on the Confucian family structure. From the first section on women's alienation within the household, the examinations required significant time, energy, and travel from male family members thereby causing separation from the family in terms of both physical and emotional space. Additionally, men who were taking the examination would form social networks among candidates from the same areas or examination year whose interests might conflict with the best interests of the household. This creates an ironic situation where husbands, fathers, and sons were not cultivating the Confucian familial relationships that are crucial for maintaining an effective government in order to study for an examination on Confucianism. 
This separation of men from women thereby necessitates that women must fulfill the aspects of filial piety that the men were unable to fulfill due to the excessive strain of the examinations. While burdensome, women did gain some unintentional benefits from these new expectations to provide both moral and economic support for the family. The first of these benefits is the increased informal power women held in the household. This means that the more women were held responsible for, the more say they had in the affairs of the household than was traditional. Second, women gained higher visibility in the outer world, through both their writings which became more and more widespread through the booming commercial printing culture as well as being more visible as fulfilling professional roles such as becoming a teacher of the inner chamber. Third, women that were able to handle the increased expectations gained the managerial skills that would allow them to succeed in their newly visible activities. Finally, the increased visibility of women through their writings also meant that women could offer political criticism and voice political concerns previously unheard of. Through these changes it can be shown that the Confucian civil service examinations had significant negative and positive impacts on Confucian gender roles. 
Brook, Timothy. 1999. The Confusions of Pleasure: Commerce and Culture in Ming China. Berkeley: University of California Press.

Chaffee, John W. 1985. The Thorny Gates of Learning in Sung China. Cambridge: Cambridge University Press.

Chang, Kang-i Sun and Haun Saussey. 1999. Women Writers of Traditional China: An Anthology of Poetry and Criticism. Stanford: Stanford University Press.

Elman, Benjamin A. 2013. Civil Examinations and Meritocracy in Late Imperial China. Cambridge: Harvard University Press.

Ho, Ping-ti. 1962. The Ladder of Success in Imperial China: Aspects of Mobility 1368-1911. New York: Columbia University Press.

Ko, Dorothy. 1994. Teachers of the Inner Chambers: Women and Culture in SeventeenthCentury China. Stanford: Stanford University Press.

Mann, Susan. 1997. Precious Records: Women in China's Long Eighteenth Century. Stanford: Stanford University Press.

Mann, Susan. 2007. The Talanted Women of the Zhang Family. Berkeley: University of California Press. 
Miyazaki, Ichisada. 1976. China's Examination Hell: The Civil Service Examinations of Imperial China. New Haven: Yale University Press.

Schneewind, Sarah. 2006. A Tale of Two Melons: Emperor and Subject in Ming China. Indianapolis: Hackett Publishing Company Inc. 